\title{
Epidemiology of liver cancer in Europe
}

\author{
F Xavier Bosch MD PhD, Josepa Ribes MD
}

\begin{abstract}
FX Bosch, J Ribes. Epidemiology of liver cancer in Europe. Can J Gastroenterol 2000;14(7):621-630. Liver cancer (LC) ranks fifth in frequency in the world, with an estimated 437,000 new cases in 1990. The estimates are different when LC frequency is analyzed by sex and geographical areas. In developed areas, the estimates are 53,879 among men and 26,939 among women. In developing areas, the estimates are 262,043 in men and 93,961 in women. Areas of highest rates include Eastern and South Eastern Asia, Japan, Africa and the Pacific Islands (LC age-adjusted incidence rates [AAIRs] ranging from 17.6 to 34.8). Intermediate rates (LC AAIRs from 4.7 to 8.9 among men) are found in Southern, Eastern and Western Europe, Central America, Western Asia and Northern Africa. Low rates are found among men in Northern Europe, America, Canada, South Central Asia, Australia and New Zealand (LC AAIRs range from 2.7 to 3.2). In Europe, an excess of LC incidence among men compared with women is observed, and the age peak of the male excess is around 60 to 70 years of age. Significant variations in LC incidence among different countries have been described and suggest differences in exposure to risk factors. Chronic infection with the hepatitis $B$ virus (HBV) and hepatitis $\mathrm{C}$ virus (HCV) in the etiology of $\mathrm{LC}$ is well established. In Europe, $28 \%$ of $\mathrm{LC}$ cases have been attributed to chronic $\mathrm{HBV}$ infection and $21 \%$ to $\mathrm{HCV}$ infection. Other risk factors such as alcohol consumption, cigarette smoking and oral contraceptives may explain the residual variation within countries. Interactions among these risk factors have been postulated. New laboratory techniques and biological markers such as polymerase chain reaction detection of HBV DNA and HCV RNA, as well as specific mutations related to $L C$, may help to provide quantitative estimates of the risk related to each these factors.
\end{abstract}

Key Words: Europe; Hepatitis B virus; Hepatitis C virus; Liver cancer

\section{Épidémiologie du cancer du foie en Europe}

RÉSUMÉ : Le cancer du foie se classe au cinquième rang par ordre de fréquence dans le monde; on en a dénombré environ 437000 nouveaux cas en 1990. Ces estimations sont différentes lorsque l'on analyse la fréquence du cancer du foie selon le sexe et les régions. Dans les pays industrialisés, 53879 hommes et 26939 femmes en seraient atteints; dans les pays en voie de développement, on note 262043 cas chez les hommes et 93961 chez les femmes. Les régions les plus touchées sont, entre autres, l'Est et le Sud-Est asiatiques, le Japon, l'Afrique et les Îles du Pacifique (incidence du cancer du foie ajustée selon l'âge variant de 17,6 à 34,8). Des taux intermédiaires (ajustés selon l'âge, 4,7 à 8,9 chez les hommes) s'observent dans le Sud, l'Est et l'Ouest de l'Europe, en Amérique Centrale, dans l'Ouest asiatique et l'Afrique du Nord. Des taux faibles s'observent chez les hommes du Nord de l'Europe, de l'Amérique, du Canada, du Sud et du centre de l'Asie, de l'Australie et de la Nouvelle-Zélande (soit de 2,7 à 3,2). En Europe, on observe un plus grand nombre de cas de cancers du foie chez les hommes que chez les femmes et l'âge auquel les hommes sont le plus touchés se situe autour de 60 à 70 ans. Les importantes variations de l'incidence du cancer du foie selon les pays ont été décrites et donnent à penser qu'il y aurait des différences quant à l'exposition aux facteurs de risque. L'infection chronique au virus de l'hépatite $\mathrm{B}(\mathrm{HBV})$ et au virus de l'hépatite $\mathrm{C}$ (HCV) est bien établie dans l'étiologie du cancer du foie. En Europe, $28 \%$ des cas de cancer du foie ont été attribués à une infection à HBV chronique et $21 \%$ à une infection à HCV. Parmi les autres facteurs de risque, la consommation d'alcool, le tabagisme et la contraception orale pourraient expliquer la variation résiduelle entre les pays. Les interactions entre ces facteurs de risque ont fait l'objet de postulats. De nouvelles techniques de laboratoire et de nouveaux marqueurs biologiques comme le dépistage de l'ADN du HBV et de l'ARN du HCV par réaction en chaîne de la polymérase de même que certaines mutations spécifiques associées au cancer du foie pourraient contribuer aux estimations quantitatives du risque associé à chacun de ces facteurs.
$\mathrm{T}$ his review presents the estimates of liver cancer (LC) incidence and mortality for 1990, its geographical variations in occurrence and recent data on the distribution of some of the key risk factors in Europe. (Unless otherwise specified, the term 'Europe' includes the countries defined in Tables 1 and 2.) The key data sources are population-based

This mini-review was prepared from a presentation made at the World Congress of Gastroenterology, Vienna, Austria, September 6 to 11, 1998 Servei d'Epidemiologia i Registre del Càncer. Institut Catalià d'Oncologia, Barcelona, Spain

Correspondence: Dr F Xavier Bosch, Servei d'Epidemiologia i Registre del Càncer. Institut Catalià d'Oncologia. Av Gran Via s/n,

Km 2,7, L'Hospitalet de Llobregat, 08907 Barcelona, Spain. Telephone +34-93-2607812, fax +34-93-260-7787, e-mail serc@ico.scs.es Received for publication July 27, 1999. Accepted August 5, 1999 
TABLE 1

Crude, age-adjusted incidence rates (AAIRS) per 100,000 population and sex ratio of liver cancer in Europe. (Estimates for the year 1990)

\begin{tabular}{|c|c|c|c|c|c|}
\hline \multirow[b]{2}{*}{ Countries } & \multicolumn{2}{|c|}{$\begin{array}{l}\text { Crude incidence } \\
\text { rates }\end{array}$} & \multicolumn{2}{|c|}{ AAIRS } & \multirow{2}{*}{$\begin{array}{c}\text { Sex } \\
\text { ratio* } \\
\text { (AAIRS) }\end{array}$} \\
\hline & Men & Women & Men & Women & \\
\hline Developed world & 9.73 & 4.57 & 7.64 & 2.65 & 2.88 \\
\hline Developing world & 12.43 & 4.62 & 17.84 & 6.17 & 2.89 \\
\hline Eastern Europe & 5.73 & 4.69 & 5.23 & 2.82 & 1.85 \\
\hline Belarus & 4.53 & 3.12 & 4.15 & 1.96 & 2.12 \\
\hline Bulgaria & 7.32 & 5.28 & 4.91 & 3.02 & 1.63 \\
\hline Czech Republic & 8.57 & 4.94 & 6.71 & 2.82 & 2.38 \\
\hline Hungary & 8.88 & 6.65 & 6.33 & 3.54 & 1.79 \\
\hline Moldova & 4.31 & 3.30 & 4.49 & 2.60 & 1.73 \\
\hline Poland & 6.18 & 5.44 & 5.62 & 3.58 & 1.57 \\
\hline Romania & 4.89 & 3.64 & 4.02 & 2.48 & 1.62 \\
\hline $\begin{array}{l}\text { Russian } \\
\text { Federation }\end{array}$ & 5.17 & 4.56 & 5.18 & 2.75 & 1.88 \\
\hline Slovakia & 8.01 & 4.58 & 7.30 & 3.16 & 2.31 \\
\hline Ukraine & 5.98 & 4.85 & 5.05 & 2.68 & 1.88 \\
\hline Northern Europe & 4.00 & 2.60 & 2.66 & 1.38 & 1.93 \\
\hline Denmark & 6.08 & 4.28 & 3.85 & 2.19 & 1.76 \\
\hline Estonia & 4.82 & 3.39 & 4.16 & 1.93 & 2.16 \\
\hline Finland & 6.45 & 5.84 & 4.89 & 3.00 & 1.63 \\
\hline Iceland & 3.64 & 1.48 & 3.18 & 1.09 & 2.92 \\
\hline Ireland & 3.29 & 1.92 & 2.72 & 1.33 & 2.04 \\
\hline Latvia & 4.79 & 3.12 & 4.11 & 1.83 & 2.25 \\
\hline Lithuania & 4.59 & 2.93 & 4.05 & 1.89 & 2.14 \\
\hline Norway & 2.91 & 2.15 & 1.84 & 1.15 & 1.60 \\
\hline Sweden & 6.52 & 4.23 & 3.61 & 1.94 & 1.86 \\
\hline United Kingdom & 3.35 & 2.01 & 2.19 & 1.08 & 2.03 \\
\hline Southern Europe & 12.57 & 6.15 & 8.89 & 3.41 & 2.61 \\
\hline Albania & 3.70 & 2.42 & 5.21 & 2.83 & 1.84 \\
\hline $\begin{array}{l}\text { Bosnia } \\
\text { Herzegovina }\end{array}$ & 5.11 & 3.83 & 5.90 & 3.43 & 1.72 \\
\hline Croatia & 5.99 & 4.51 & 4.80 & 2.64 & 1.82 \\
\hline Greece & 19.36 & 8.76 & 12.09 & 4.65 & 2.60 \\
\hline Italy & 16.60 & 7.41 & 10.81 & 3.74 & 2.89 \\
\hline Macedonia & 11.55 & 5.11 & 12.09 & 4.65 & 2.60 \\
\hline Malta & 2.15 & 1.85 & 1.72 & 1.21 & 1.42 \\
\hline Portugal & 5.27 & 2.43 & 3.95 & 1.48 & 2.67 \\
\hline Slovenia & 3.52 & 1.60 & 2.95 & 1.00 & 2.95 \\
\hline Spain & 10.57 & 5.32 & 7.39 & 2.89 & 2.56 \\
\hline Yugoslavia & 9.35 & 7.34 & 7.75 & 4.89 & 1.58 \\
\hline Western Europe & 6.93 & 3.05 & 4.89 & 1.55 & 3.15 \\
\hline Austria & 11.22 & 5.59 & 8.04 & 2.69 & 2.99 \\
\hline Belgium & 2.59 & 1.79 & 1.71 & 0.89 & 1.92 \\
\hline France & 11.13 & 3.16 & 7.95 & 1.72 & 4.62 \\
\hline Germany & 4.80 & 3.27 & 3.36 & 1.55 & 2.17 \\
\hline Luxembourg & 5.26 & 2.04 & 3.81 & 0.87 & 4.38 \\
\hline The Netherlands & 2.05 & 1.10 & 1.59 & 0.67 & 2.37 \\
\hline Switzerland & 9.02 & 2.82 & 6.12 & 1.49 & 4.11 \\
\hline
\end{tabular}

*Men's AAIRs to women's AAIRS. Data calculated using Globocan Statistical Software (France)

cancer registries $(1,2)$ and the World Health Organization (WHO) mortality databank (3). National age-adjusted incidence rates (AAIRs) and age-adjusted mortality rates
TABLE 2

Crude, age-adjusted mortality rates (AAMRs) per 100,000 population of liver cancer, and fatality rate in Europe. (Estimates for the year 1990)

\begin{tabular}{|c|c|c|c|c|c|c|}
\hline \multirow[b]{2}{*}{ Countries } & \multicolumn{2}{|c|}{$\begin{array}{c}\text { Crude mortality } \\
\text { rates }\end{array}$} & \multicolumn{2}{|c|}{ AAMR } & \multicolumn{2}{|c|}{ Fatality rate* } \\
\hline & Men & Women & Men & Women & Men & Women \\
\hline Developed world & 9.49 & 5.05 & 7.38 & 2.83 & 0.96 & 1.07 \\
\hline Developing world & 12.02 & 4.49 & 17.28 & 6.02 & 0.97 & 0.98 \\
\hline Eastern Europe & 6.23 & 4.90 & 5.68 & 2.93 & 1.09 & 1.04 \\
\hline Belarus & 4.15 & 2.62 & 3.79 & 1.59 & 0.91 & 0.81 \\
\hline Bulgaria & 7.66 & 5.00 & 5.21 & 2.91 & 1.06 & 0.96 \\
\hline Czech Republic & 9.86 & 6.53 & 7.70 & 3.70 & 1.15 & 1.31 \\
\hline Hungary & 11.76 & 7.41 & 8.34 & 3.94 & 1.32 & 1.11 \\
\hline Moldova & 4.00 & 3.12 & 4.17 & 2.45 & 0.93 & 0.94 \\
\hline Poland & 6.66 & 6.22 & 6.08 & 4.05 & 1.08 & 1.13 \\
\hline Romania & 4.23 & 3.28 & 3.48 & 2.23 & 0.87 & 0.90 \\
\hline $\begin{array}{l}\text { Russian } \\
\text { Federation }\end{array}$ & 5.87 & 4.80 & 5.90 & 2.87 & 1.14 & 1.04 \\
\hline Slovakia & 7.44 & 4.88 & 6.76 & 3.36 & 0.93 & 1.06 \\
\hline Ukraine & 6.18 & 4.73 & 5.22 & 2.61 & 1.03 & 0.97 \\
\hline Northern Europe & 3.94 & 2.81 & 2.59 & 1.44 & 0.97 & 1.04 \\
\hline Denmark & 3.48 & 2.41 & 2.17 & 1.27 & 0.56 & 0.56 \\
\hline Estonia & 5.09 & 3.46 & 4.44 & 1.92 & 1.07 & 0.99 \\
\hline Finland & 4.31 & 4.00 & 3.24 & 2.02 & 0.66 & 0.67 \\
\hline Iceland & 3.53 & 1.65 & 3.18 & 1.18 & 1.00 & 1.08 \\
\hline Ireland & 3.69 & 2.71 & 2.93 & 1.73 & 1.08 & 1.30 \\
\hline Latvia & 3.50 & 2.29 & 3.00 & 1.29 & 0.73 & 0.70 \\
\hline Lithuania & 4.09 & 2.63 & 3.60 & 1.64 & 0.89 & 0.87 \\
\hline Norway & 2.37 & 1.97 & 1.50 & 0.95 & 0.82 & 0.83 \\
\hline Sweden & 8.17 & 6.43 & 4.38 & 2.84 & 1.21 & 1.46 \\
\hline United Kingdom & 3.42 & 2.30 & 2.21 & 1.19 & 1.01 & 1.10 \\
\hline Southern Europe & 15.12 & 9.18 & 10.55 & 4.90 & 1.19 & 1.44 \\
\hline Albania & 3.22 & 2.21 & 4.61 & 2.60 & 0.88 & 0.92 \\
\hline $\begin{array}{l}\text { Bosnia } \\
\text { Herzegovina }\end{array}$ & 3.81 & 2.90 & 4.48 & 2.60 & 0.76 & 0.76 \\
\hline Croatia & 3.02 & 2.43 & 2.44 & 1.38 & 0.51 & 0.52 \\
\hline Greece & 24.14 & 14.33 & 14.77 & 7.27 & 1.22 & 1.56 \\
\hline Italy & 20.87 & 11.59 & 13.37 & 5.60 & 1.24 & 1.50 \\
\hline Macedonia & 13.98 & 8.02 & 14.77 & 7.27 & 1.22 & 1.56 \\
\hline Malta & 2.97 & 2.62 & 2.39 & 1.63 & 1.39 & 1.35 \\
\hline Portugal & 5.56 & 3.68 & 4.10 & 2.15 & 1.04 & 1.45 \\
\hline Slovenia & 6.03 & 4.46 & 5.07 & 2.59 & 1.72 & 2.59 \\
\hline Spain & 12.60 & 8.60 & 8.64 & 4.52 & 1.17 & 1.56 \\
\hline Yugoslavia & 9.56 & 7.25 & 7.91 & 4.83 & 1.02 & 0.99 \\
\hline Western Europe & 8.70 & 3.96 & 6.06 & 1.91 & 1.24 & 1.23 \\
\hline Austria & 9.68 & 4.87 & 6.88 & 2.23 & 0.86 & 0.83 \\
\hline Belgium & 3.43 & 2.52 & 2.20 & 1.17 & 1.29 & 1.31 \\
\hline France & 14.56 & 4.24 & 10.20 & 2.18 & 1.28 & 1.27 \\
\hline Germany & 6.35 & 4.36 & 4.41 & 1.97 & 1.31 & 1.27 \\
\hline Luxembourg & 4.74 & 3.05 & 3.36 & 1.58 & 0.88 & 1.82 \\
\hline The Netherlands & 2.43 & 1.64 & 1.83 & 0.94 & 1.15 & 1.40 \\
\hline Switzerland & 8.04 & 3.10 & 5.42 & 1.61 & 0.86 & 1.08 \\
\hline
\end{tabular}

*Mortality/incidence (AAMRs/AAIRs). Data calculated using Globocan Statistical Software (France)

(AAMRs) of LC have been obtained by combining available data by countries (4-6). (Unless otherwise specified, AAIRs and AAMRs are annual average per 100,000, and the stan- 
dard population used for the adjustement is the world standard population as defined in reference 1.) In this review, the term LC largely corresponds ( $80 \%$ to $85 \%$ ) to hepatocellular carcinoma.

\section{ESTIMATED NUMBER OF LC CASES}

It has been estimated that, in 1990, approximately 437,000 new cases of LC became apparent worldwide, accounting for $5.4 \%$ of all human cancer cases. The number estimated is different when analyzed by sex and level of development of geographical areas. In developed areas, the number estimated is 53,879 among men and 26,939 among women. In developing areas, the estimates are 262,043 and 93,961, respectively (4).

Europe, largely a developed continent, accounted for 41,085 new cases of LC $-1.8 \%$ of all cancer cases in 1990. The number of new LC cases is 25,000 , or $2.1 \%$ of all cancer cases, among men, and 16,000 , or $1.4 \%$ of all cancers, among women. In the same year, 48,586 patients died as a consequence of the disease (4).

LC is the fifth most common cancer in the world; it also ranks fifth among men and eighth among women. In Europe, LC ranks 13th among men and 14th among women. This ranking holds true when grouping colon with rectum, mouth with pharynx and all hematological neoplasms (4).

\section{GEOGRAPHIC VARIATION IN LC INCIDENCE}

In developing countries, the annual AAIR of LC is estimated to be 17.8 among men and 6.2 among women -2.3 -fold higher than in developed countries (LC AAIRS 7.6 and 2.6, respectively). Figure 1 shows AAIRs of LC among men by geographical areas worldwide. Areas of highest rates include Eastern and South Eastern Asia, Africa (except Northern Africa) and the Pacific Islands (LC AAIRs ranging from 17.6 to 34.8). Japan, a developed country in Eastern Asia, has the highest LC AAIRs among developed countries worldwide (AAIR 27.6 in men). Intermediate rates (LC AAIR from 4.7 to 8.9 among men) are found in Southern, Eastern and Western Europe; Central America; Western Asia; and Northern Africa. Low rates are found among men in the United States, Canada, South Central Asia, Australia, New Zealand and Northern Europe (LC AAIRs range from 2.7 to 3.2).

Table 1 shows the crude incidence rates and AAIRs for LC in Europe by sex and country. Southern Europe has the three countries with the highest LC AAIRs in Europe Greece, Italy and Macedonia (AAIRs 12.1, 10.8 and 12.1, respectively, among men). The region with the second highest AAIRs is Eastern Europe (AAIRs ranging from 4.0 to 7.3 among men), and the region with the third highest AAIRs is Western Europe (AAIRs ranging from 1.6 to 8.0 among men). In Western Europe, Austria, France and Switzerland have AAIRs close to those of Southern Europe (among men, 8.0, 7.9 and 6.1, respectively) (4).

\section{MORTALITY FROM LC}

Mortality statistics on LC have recognized limitations because a varying proportion of cases are reported as unspecified LC if primary or secondary, and because the coding recom-

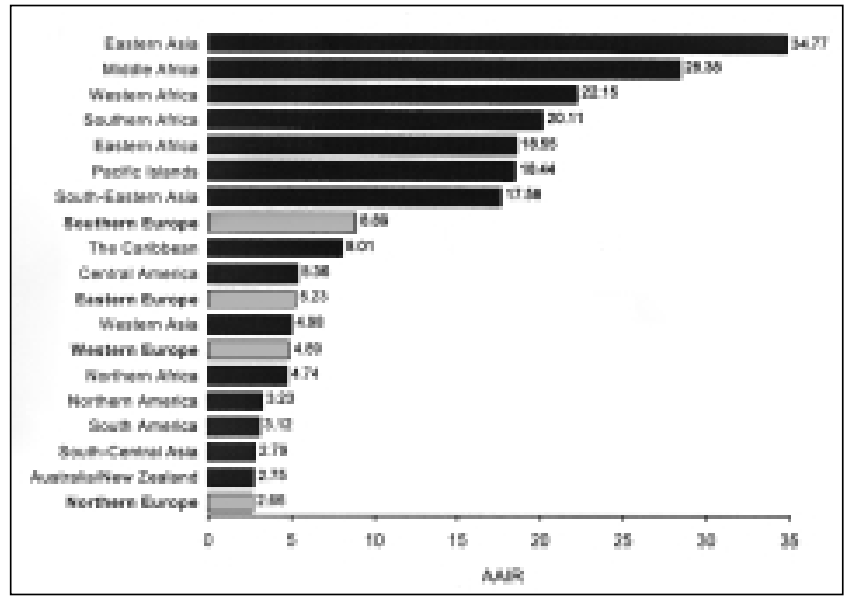

Figure 1) Summary estimates of the estimated age-adjusted incidence rates (AAIRs) of liver cancer in men

mendations concerning metastatic disease to the liver have changed from the eighth to the ninth revisions of the International Classification of Disease (ICD) coding manual (ICD 8 and ICD 9) $(7,8)$. The probability of misclassifying primary LC with liver metastasis is paradoxically high in developed countries, where LC is rarer than liver metastases among patients presenting with a liver mass.

Crude estimates and AAMRs for LC (Table 2) present a similar pattern to that observed in incidence rates $(4,6)$. The fatality ratio (mortality to incidence ratio) is around 1 , indicating that the majority of patients do not survive one year.

\section{LC MORTALITY AMONG MIGRANTS FROM HIGH RISK COUNTRIES}

In some European countries, high rates of LC mortality (AAMRs) are seen for both sexes among migrants from high risk areas of the world compared with those of the host population. In France, during the period from 1979 to 1985, higher LC AAMRs were found among sub-Saharan and Eastern African migrants than among the French population $(9,10)$. In England and Wales, during the period 1970 to 1985, LC AAMRs among migrants from the Indian subcontinent (11), East and West Africa, and the Caribbean (12) were found to be higher than those among the English and Welsh populations. Similar observations have been reported in Canada, where a higher risk for mortality from LC has been found among Italian migrants compared with that of the Canadian population (13).

In some European countries, the introduction of hepatitis $B$ virus (HBV) vaccination to newborns from HBV carrier mothers and the universal use of HBV vaccines in the early 1990s may have accelerated the reduction of LC mortality in successive generations of migrants from high risk countries.

\section{TRENDS IN LC INCIDENCE}

International variation in the coding and registration practices for primary and secondary LC makes the interpretation of long term time trends difficult. During the period 1982 to 1992, population-based cancer registries in Europe $(1,2)$ sug- 


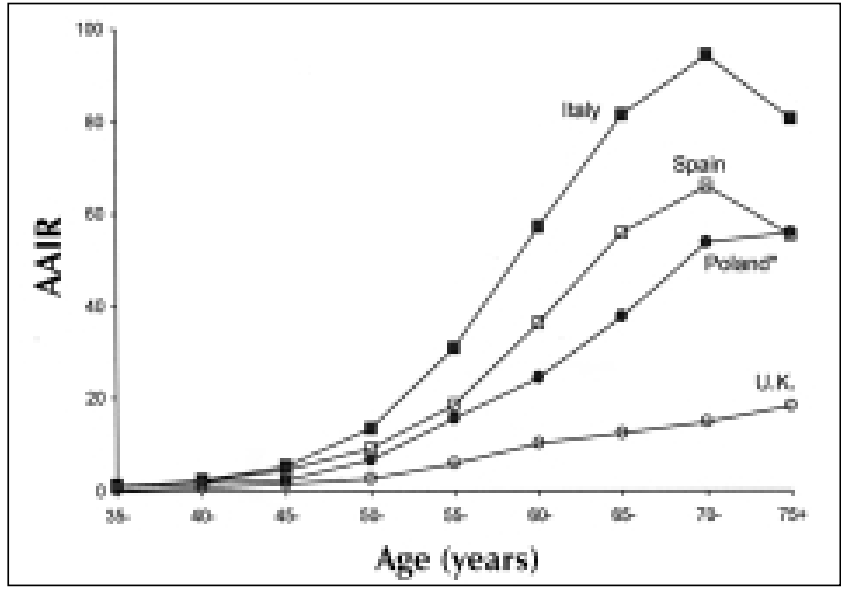

Figure 2) Age-specific incidence rates (AAIRs) of liver cancer in men in selected European countries during the period 1988 to 1992. *Pooled (four registries, 1988 to 1992). U.K. United Kingdom

gested, for both sexes, increasing trends in LC incidence in the Czech Republic, Finland, Germany, Italy (14), Latvia, The Netherlands and the United Kingdom (15). In France (16), Iceland, Ireland, Poland, Spain and Switzerland, increasing trends have been observed only among men. A decrease in the LC AAIRs has been observed in Belarus, Denmark, Estonia, Norway and Sweden (17).

In Japan, since the early 1970 s, a $15 \%$ to $20 \%$ increase in the incidence of LC has been observed for both sexes and across age groups (18). This increased incidence has been attributed to hepatitis $\mathrm{C}$ virus (HCV)-induced LC. The trend has been associated with a massive exposure to $\mathrm{HCV}$ in the years following World War II in relation to vaccination campaigns against tuberculosis and intravenous drug abuse (19). A recent study conducted in France predicts, according to $\mathrm{HCV}$ infection trends, the natural history of liver disease and the French mortality data, that the number of HCV related LC deaths will increase approximately $150 \%$ in the next 30 years in the absence of an effective treatment (20). $\mathrm{HCV}$ infection is a public health concern in Europe, where 1.2 million individuals are estimated to be carriers of an ac- tive HCV infection (20). These data indicate that, if Europe follows the same trends predicted in France, an increase in HCV-related LC may be expected in Europe in the next decades.

\section{AGE AND SEX DISTRIBUTION IN LC INCIDENCE}

Worldwide, in both high and low risk populations, LC AAIRs increase progressively with age. In high risk areas, in Africa and China, cases of HBV-related LC may occur as early as 15 years of age and reach a peak at 40 years of age. In low risk areas in the world, the rise occurs much later, usually after 40 years of age (22). In Japan, where HCV-related LC cases predominate, the incidence among men sharply increases after the age interval 45 to 50 years, and a peak occurs around 65 years of age. In Europe (Figure 2) the LC age distribution shows the same pattern as that of Japan but with threefold lower LC AAIRs (4) and with an average age at onset of the HBV-related LC of around 59 years of age and around 66 in HCV-related LC cases (14).

In Europe, an excess of LC incidence among men compared with that among women is generally observed (ratio of AAIRs in men to women 1.4 to 4.6; Table 1), and the peak age of the male excess is around 60 to 70 years of age (22). The estimated correlation between LC AAIRs in men and women in 38 European countries is extremely high (correlation coefficient $[C C]=0.83, P<0.001)(4)$, suggesting that viral risk factors for LC affect both sexes in a similar manner (23). The male excess of LC may be explained by the sexspecific exposure rates of additional risk factors such as alcohol consumption, cigarette smoking and hormonal factors. A minor contribution to the variance of the sex-specific incidence rates may be attributable to poorly described host factors, as suggested by data from high risk countries (24).

\section{RISK FACTORS FOR LC}

Viral factors: Chronic HBV and HCV infections are well established etiological factors for LC (25-27). Risk estimates for seropositivity of hepatitis B surface antigen $(\mathrm{HBsAg})$ and LC range from three to 30 in case-control studies and from

TABLE 3

Risk factors of liver cancer and estimates of the attributable fractions

\begin{tabular}{|c|c|c|c|c|c|c|}
\hline \multirow[b]{2}{*}{ Risk factors } & \multicolumn{2}{|c|}{$\begin{array}{l}\text { Low risk countries in Europe } \\
\text { and the United States }\end{array}$} & \multicolumn{2}{|c|}{ Japan } & \multicolumn{2}{|c|}{$\begin{array}{l}\text { High risk countries } \\
\text { in Africa and Asia }\end{array}$} \\
\hline & Estimate (\%) & Range (\%) & Estimate (\%) & Range (\%) & Estimate (\%) & Range (\%) \\
\hline Hepatitis C virus* & 60 & $12-64 \%$ & 50 & $48-80$ & $<10 \%$ & $\mathrm{NE}$ \\
\hline Aflatoxin & Limited exposure & & Limited exposure & & Important exposure ${ }^{+}$ & \\
\hline Alcohol & $<15^{\ddagger}$ & $<15-45$ & $<20$ & & $11-30 \%$ & NE \\
\hline Oral contraceptives & & $10-50^{4}$ & $\mathrm{NE}$ & & $8 \% * *$ & $\mathrm{NE}$ \\
\hline Other & $<8$ & & & & $5 \%$ & \\
\hline
\end{tabular}

Attributable fractions do not necessarily add to $100 \%$ because of multiple exposures and possible interactions between risk factors. ${ }^{*}$ Not including double infections with hepatitis B virus and hepatitis $C$ virus. Very few studies using second-generation assays are available; ${ }^{\dagger}$ Attributable risk not quantified; ${ }^{\ddagger}$ Estimates for the United States; ${ }^{\S}$ Estimates for hepatitis B surface antigen-negative black men older than 50 years of age (one study); ${ }^{\text {Res- }}$ tricted to liver cancer in women; **Restricted to liver cancer in black women (one study). NE Not evaluated. Data from references 


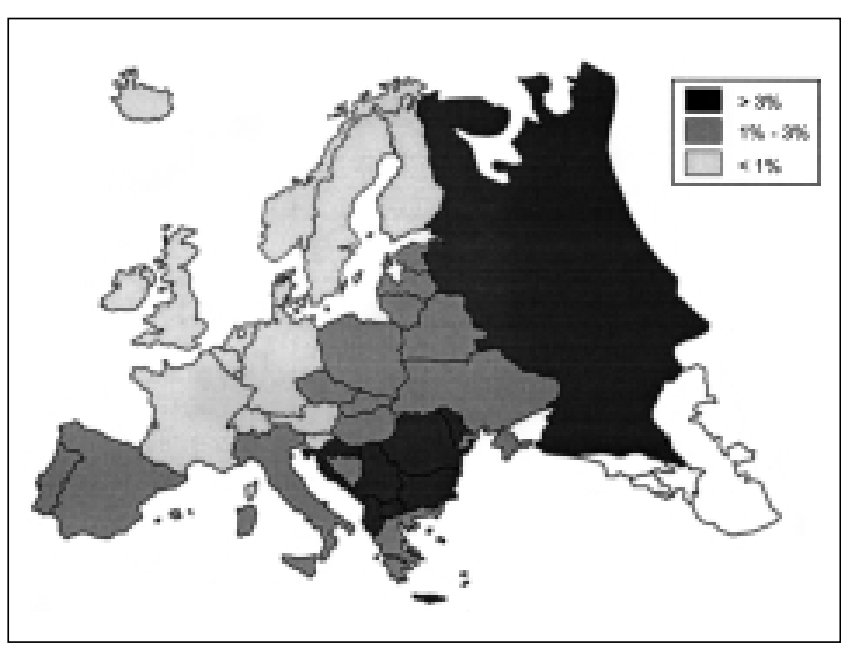

Figure 3) Estimates of hepatitis B surface antigen seroprevalence in the European population by country

5.3 to 148 in cohort studies (28). A meta-analysis comprising studies published before 1998 estimated the relative risk as 17 for anti-HCV carriers who are HBsAg-negative (29). Table 3 shows estimates of the attributable fractions for the main risk factors associated with LC. In Europe, 28\% of LC cases have been attributed to chronic HBV infection. The fraction of LC cases attributable to HCV infection is $21 \%$ (30).

WHO compiles data on country-specific estimates of the HBsAg and anti-HCV prevalences worldwide $(31,32)$. In Europe, the level of HBsAg endemicity generally increases from North to South and from West to East. Unexpectedly, a high prevalence of $\mathrm{HBsAg}$ ( $5 \%$ to $12 \%$ ) has been found in many parts of Central and Eastern Europe and the New Independent States of the former Soviet Union (Figure 3). Among blood donors in Europe, the prevalence of anti-HCV ranges from a low $0.23 \%$ in Scandinavia to a high $1.15 \%$ in ltaly (20) (Figure 4). The Mediterranean area has an intermediate prevalence of hepatitis delta virus (HDV), although this infection is endemic in Southern Italy and Greece (33). $\mathrm{HBsAg}$ and anti-HCV prevalences in LC cases are shown in Table 4 by European countries (34-50). Marked variations among European countries have been found in LC cases related to hepatitis virus infection. In Southern countries, the prevalence of $\mathrm{HCV}$ infection in $\mathrm{LC}$ cases ranges from $40 \%$ to $76 \%$ in Italy and Spain, to $12 \%$ to $14 \%$ in Greece. In contrast, HBV infection in LC cases is more prevalent in Greece (61\% to $71 \%$ ) than in other Mediterranean countries, with HBsAg prevalences ranging from $7 \%$ to $26 \%$. In the Northern countries, HCV infection in LC cases is important ( $24.7 \%$ to $45 \%$ ). Correlations between LC AAIRS, and the $\mathrm{HBsAg}$ and anti-HCV prevalences have been explored in the 15 countries of the European Community (EC) and Norway, Iceland and Switzerland, among men. A significant CC has been found for HBsAg $(\mathrm{CC}=0.74, \mathrm{P}<0.001)$ and for antiHCV (CC=0.63, $\mathrm{P}<0.001$ ) (Figure 5).

Epidemiological studies based on the standard assays (radioimmunoassay and second or third generation ELISA) may have underestimated chronic infections with HBV and

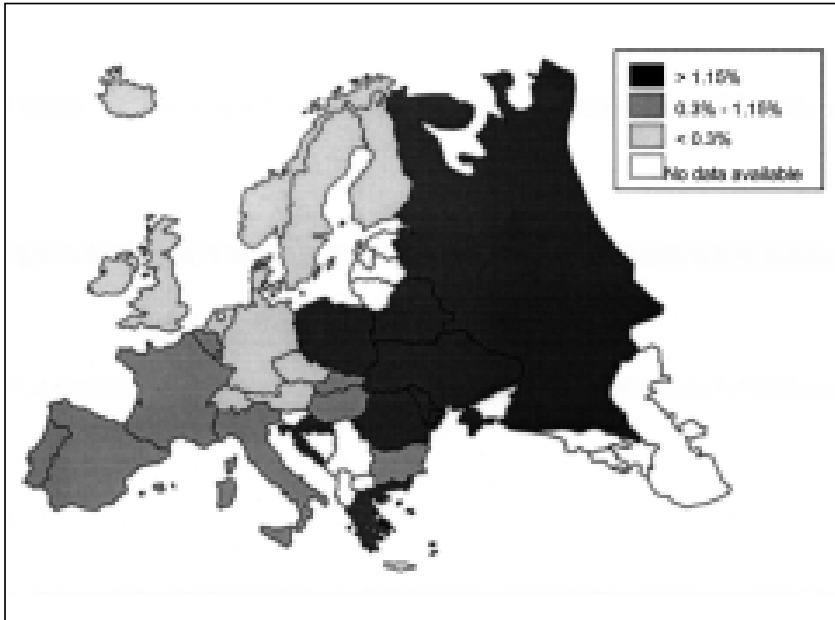

Figure 4) Estimates of the antihepatitis $C$ virus seroprevalence in the European population by country

TABLE 4

Seroprevalence of hepatitis B surface antigen ( $\mathrm{HbsAg}$ ) and antihepatitis $C$ virus (HCV) in patients with liver cancer

\begin{tabular}{lcccc}
\hline Country & Year & $\mathbf{n}$ & HBsAg & Anti-HCV \\
\hline Italy & 1992 & 212 & 7 & 71.2 \\
& 1991 & 167 & 31.7 & 58.1 \\
& 1991 & 132 & 14 & 65 \\
& 1997 & 172 & 23.8 & 40.1 \\
& 1998 & 1083 & 11.5 & 76.3 \\
Spain & 1998 & 67 & 22.4 & 64.2 \\
& 1991 & 88 & 25 & 72 \\
France & 1998 & 137 & 9.5 & 75.2 \\
& 1998 & 48 & 22.9 & 27.1 \\
Greece & 1991 & 55 & 6 & 58.2 \\
& 1995 & 65 & 61.5 & 12.3 \\
& 1998 & 56 & 71.4 & 14.3 \\
Switzerland & 1995 & 51 & 60.8 & 13.7 \\
Germany & 1992 & 40 & 1.5 & 35.0 \\
& 1998 & 22 & 13.6 & 45.5 \\
United Kingdom & 1994 & 81 & 25.9 & 24.7 \\
& 1998 & 131 & 9.9 & 6.1 \\
& 1997 & 80 & n.d. & 30 \\
\hline
\end{tabular}

Data from references $14,33-49$

HCV. To evaluate the limitations of these methods in assessing exposure to $\mathrm{HBV}$ and $\mathrm{HCV}$, a validation study was conducted in six European countries with serum samples and liver tissue from $503 \mathrm{LC}$ cases (39). HBsAg and anti-HCV were detected in $19 \%$ and $40.1 \%$ of LC cases, respectively. The presence of HBV DNA and HCV RNA was tested by polymerase chain reaction (PCR). Serum HBV DNA was detected in $82 \%$ of the HBsAg-positive LC cases, in 33\% of HBsAg-negative LC cases and in $48.9 \%$ cases who were both anti-HBsAg and antihepatitis B core antigen-positive. In $25 \%$ of LC cases without any HBV marker, HBV DNA was detected in serum. Similar results were obtained for HCV infection. HCV RNA in serum was detected in $89 \%$ and $7 \%$ of 


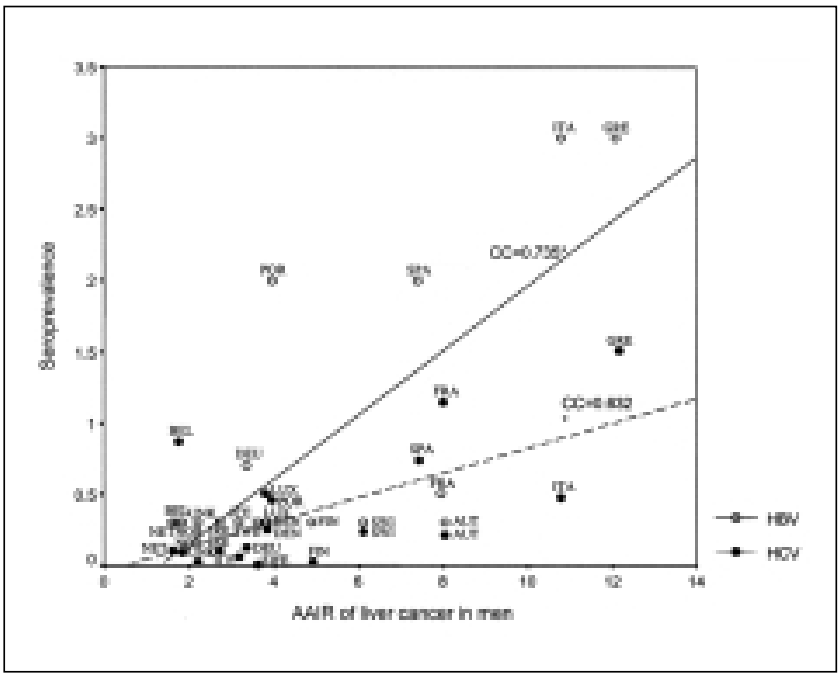

Figure 5) Correlation between the age-adjusted incidence rates (AAIRs) of liver cancer and the estimated seroprevalence of hepatitis $B$ surface antigen and antihepatitis $\mathrm{C}$ virus (HCV) infections among men. $* P<0.01$. AUT Austria; BEL Belgium; CC Correlation Coefficient; DEN Denmark; DEU Germany; HBV Hepatitis B virus; FIN Finland; FRA France; GRE Greece; ICE Iceland; IRE Ireland; ITA Italy; LUX Luxembourg; NET The Netherlands; NOR Norway; POR Portugal; SPA Spain; SWI Switzerland; UNK United Kingdom

anti-HCV-positive and -negative LC cases, respectively. In liver tissue, in $47 \%$ of $\mathrm{HBs} A g$-negative LC cases and in 26\% of anti-HCV-negative LC cases, HBV DNA and HCV RNA were detected, respectively. These results indicate that, in Europe, between $33 \%$ and $47 \%$ of the HBsAg-negative LC cases may be related to HBV, and between $7 \%$ and $26 \%$ of the anti-HCV-negative LC cases may be related to HCV. Hepatitis $\mathrm{G}$ virus (HGV) was also tested by PCR, and HGV RNA was detected in serum in $7 \%$ of $57 \mathrm{LC}$ cases. Close to $15 \%$ of the LC cases were negative for any of the three hepatic viruses tested (39).

A case-control study conducted in Italy reported that the risk for $\mathrm{LC}$ in relation to $\mathrm{HGV}$ after adjusting for $\mathrm{HBV}$ and HCV infections was 7.3 (CI 95\% 1.7 to 30.6) and that the estimated population attributable risk for $\mathrm{HGV}$ was $4 \%$. In the same study, the estimated population-attributable risks for HBV (HBsAg-positive) and HCV (HCV RNA-positive) were $22 \%$ and $36 \%$, respectively. The authors concluded that there were insufficient data to establish the role of HGV infection in the LC (38). Worldwide, few studies have suggested a specific hepatotropic effect of HGV, and it seems that coinfection with chronic HBV or HCV infections does not worsen the clinical course of liver disease (51-53). These studies suggest a major impact of HBV and HCV infection but not of $\mathrm{HGV}$ in liver carcinogenesis.

Alcohol: Chronic alcohol abuse and alcoholic cirrhosis have long been recognized as a cause of LC. However, it is not certain whether alcohol is a true carcinogen or whether its association with LC is related to repeated episodes of alcoholinduced hepatocellular injury and regeneration or iron accumulation, or whether alcohol abuse is associated with the presence of infection with HBV and/or HCV (54). Some

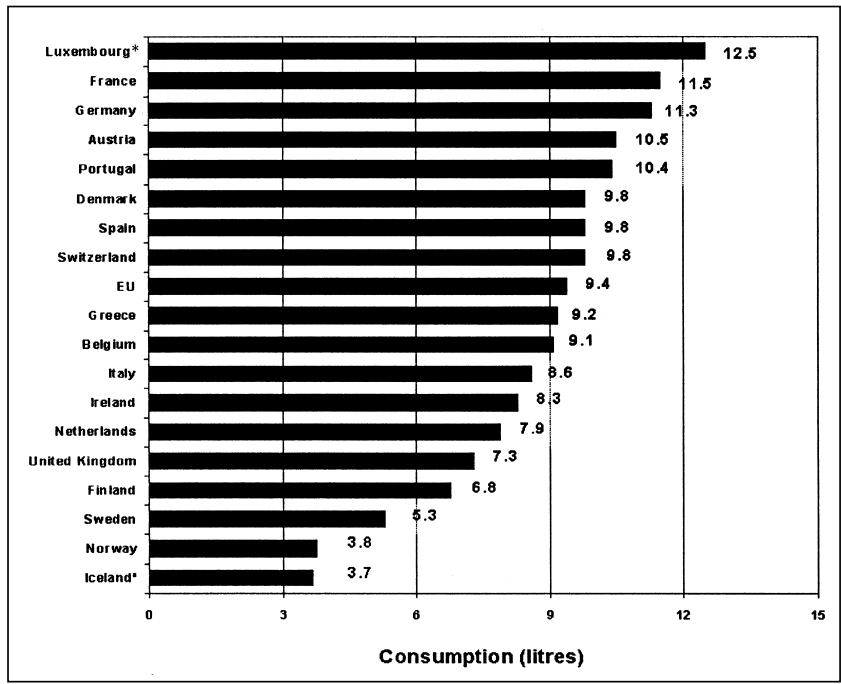

Figure 6) Annual alcohol consumption (litres of pure alcohol per head) in the year 1993 for some European countries. *1992 data. EU European Union

studies have found a dose-response relationship between total alcohol consumption and the risk of cirrhosis and LC (5558). Several epidemiological studies among alcoholics have described a high seroprevalence of HBV (16\% to $70 \%)$ and HCV markers ( $10 \%$ to $20 \%$ ) compared with a background population prevalence of close to $5 \%$ and less than $1 \%$, respectively. These prevalences are even higher in LC patients who are also alcoholics (27\% to $81 \%$ of HBV markers and $50 \%$ to $77 \%$ of $\mathrm{HCV}$ markers), suggesting an interaction between alcohol and viral infections in the etiology of LC (54). In the $\mathrm{EC}$, the consumption of alcoholic beverages has steadily declined since 1980, following an increase in the 1970s. Figure 6 shows the annual alcohol consumption (litres of pure alcohol per head) in the year 1993 in the EC and Norway, Iceland and Switzerland (59).

The attributable fraction reported in Table 3 for alcohol may be an underestimate in some countries where alcohol consumption is high. For example, a recent report from Northern Italy has estimated that the attributable fraction for alcohol in LC cases was 45\%, representing the first risk factor for LC (38).

Tobacco: As shown in Table 3, the attributable fraction estimated for tobacco use in developed countries is around $12 \%$. An association between tobacco smoking and $\mathrm{HBsAg}$ negative LChas been reported (60). However, several studies could not find any significant association, and the available data do not support an interaction of tobacco with alcohol consumption in liver carcinogenesis. In populations with a high prevalence of long term cigarette smokers, the secular trend of LC incidence or mortality has not paralleled smoking trends or trends in lung cancer mortality. There is insufficient evidence to regard this association as causal (61).

Oral contraceptives: Several case-control studies conducted in developed countries, where a substantial number of women have used oral contraceptives for extended periods of time, have found risks between 1.6 to 5.5 among those who 
have ever used oral contraceptives; a relationship with duration of use was observed in some (62). In populations with widespread use of oral contraceptives and where $\mathrm{HBV}$ is rare, between $10 \%$ and $50 \%$ of the LC cases among women is attributable to long term use of oral contraceptives (Table 3). However, the evidence to support these estimates is limited, first, because other key risk factors such as HCV have been properly evaluated in few studies, and second, because LC in women is rare and most studies are based on few cases. Finally, analysis of the mortality trends for LC in women in the United Kingdom, United States, Japan and Sweden provide no support for a measurable effect of oral contraceptives on mortality due to LC $(17,63)$. Further studies are needed to clarify and quantify the role of oral contraceptives in liver carcinogenesis. These should include a substantial number of cases and evaluate the concurrent effect of other risk factors using state-of-the-art technology (ie, using PCR methods to assess exposure to $\mathrm{HBV}$ and $\mathrm{HCV}$ ).

Aflatoxin: In most countries in Africa and Asia, exposure to aflatoxin from contamined food is common. Several ecological studies have shown a correlation between LC incidence and aflatoxin consumption at the population level (64), but the finding is not entirely consistent (65). A recognized limitation of these studies is the uncertainty concerning the lifetime quantification of individual exposure to aflatoxin. Casecontrol studies using either dietary questionnaires or biomarkers of recent exposure to aflatoxin (ie, urinary alflatoxin-DNA adducts or serological alflatoxin-albumin adducts) have also provided inconsistent results (66). In areas of the world where HBV infection is prevalent, an interaction between these two risk factors has been postulated. In these areas, a high prevalence of the postulated aflatoxinspecific mutations (guanine to thymine mutation at codon 249 of the $p 53$ gene) in the genome of LC cells has been observed. In geographical areas where aflatoxin exposure is very low, such as Europe, this mutation is rarely found in biopsies of LC (less than 10\%) (67).

Metabolic liver diseases: Hereditary hemochromatosis $(\mathrm{HH})$ and the subsequent iron deposits in tissues are risk factors for LC, liver cirrhosis $(68,69)$, and perhaps lung cancer and colorectal cancer $(70,71)$. The relative risk of $\mathrm{LC}$ in $\mathrm{HH}$ patients may be as high as 200. Other than cancer, iron deposits are related to heart failure, diabetes, impotence and arthritis. $\mathrm{HH}$ is underdiagnosed in the population, and estimates on the prevalence of $\mathrm{HH}$ in blood donors are as high as $0.8 \%$ to $1 \%$ among men and $0.3 \%$ to $0.5 \%$ among women $(72,73)$. The genetic determinants of $\mathrm{HH}$ are being traced, and in 1996 a gene was cloned and named 'HFE' $(74,75)$. Two identified mutations in HFE have been described, and heterozygosity or homozygosity for the mutated types is found in $82 \%$ to $100 \%$ of the patients with established $\mathrm{HH}$. Genetic testing recommendations are limited to screening families with established cases of $\mathrm{HH}$ or to establishing a diagnosis in patients with iron overload. The spectrum of diseases related to $\mathrm{HH}$ and its contribution to the burden of LC are largely unknown.

Diabetes has been associated with an increased risk of sev- eral cancers in organs such as the liver, the pancreas, the endometrium and the kidney. The biological mechanism involved in the association of diabetes and $\mathrm{LC}$ remains to be clarified. Two population-based cohort studies conducted in Sweden (76) and Denmark (77) found a fourfold higher risk for LC among diabetic patients compared with that of the general population. The excess risk remained elevated after exclusion of diabetic patients with related risk factors for LC such as alcoholism, cirrhosis and hepatitis. A case-control study conducted in Italy found a risk for LC in diabetic patients (odds ratio 2.1, 95\% CI 1.4 to 3.2) after adjustement for alcohol and tobacco consumption, body mass index, history of hepatitis and liver cirrhosis, and LC in relatives. The authors concluded that diabetes may explain $8 \%$ of LC cases in Italy (78).

\section{POPULATIONS AT HIGHEST RISK FOR LC}

Hemophiliacs: Hemophiliacs treated with blood products have been, for some time, at high risk of exposure to hepatitis viruses and human immunodeficiency virus (HIV) -1 . The risk of infection has been largely reduced because of routine screening for HBV, HCV and HIV-1 in blood banks, and following the introduction of treatment of blood concentrates and derived products with virus-inactivating procedures $(79,80)$. In the United Kingdom, a mortality cohort study was carried out in 4865 individuals with hemophilia A or B, treated between 1969 and 1985 with blood clotting factors before the introduction of the virus-inactivation procedures. As a consequence, it was assumed that most of these individuals would have been exposed to HCV infection (although the cohort was not tested for HCV). In this cohort, mortality to LC was between 5.5 and 19.7 times higher than expected in relation to the general population. Likewise, the risk was between 5.6 and 19.8 times higher for liver disease. When a concurrent HIV-1 infection was present, mortality for LC and liver disease was 15.1 and 94.4 times higher than that in the general population (81).

Intravenous drug users: Intravenous drug users (IDUs) are populations exposed to multiple viral infections including HBV, HDV, HCV, human T lymphotropic virus type 1 and HIV. The mortality among IDUs is high in young patients (younger than 45 years), and the majority of deaths are drugrelated (drug overdoses, acquired immune deficiency syndrome and accidents). Liver disease is frequent among most IDUs, but an excess of LC has not been reported (82-84).

Several studies have been conducted among IDUs to assess the role of HCV and HIV coinfections in liver damage. Higher serum levels of gamma-glutamyltranspeptidase and aspartate aminotransferase, and an increased proportion of liver cirrhosis have been described in subjects coinfected with $\mathrm{HCV}$ and HIV, compared with anti-HCV-positive IDUs without HIV $(85,86)$. Several authors found an increase of HCV RNA levels in serum when patients presented with HIV coinfection, and it has been suggested that reduction in the level of $\mathrm{CD}^{+}$cells may affect $\mathrm{HCV}$ replication $(87,88)$. Further investigation is needed to clarify 


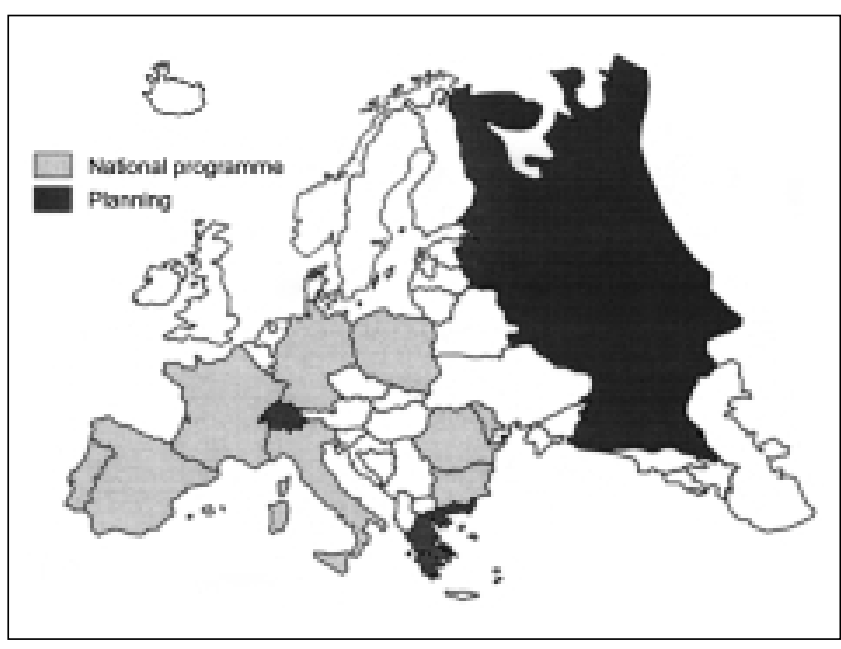

Figure 7) Hepatitis B virus vaccination programs in 2000 in Europe

whether alcohol, tobacco, analgesics or other agents have enhanced hepatotoxicity in IDUs.

Immunosuppressed patients: Some associations between immunosuppresion and viral-related cancers have been described in a study involving more than 16,000 renal transplant recipients. A 30-fold increased risk over the expected rate for cancers of the hepatobiliary tract was observed. The risk among transplant recipients was also increased for nonHodgkin lymphoma, cervical cancer, lung cancer, bladder cancer, malignant melanoma and thyroid cancer (89).

Patients with hypogammaglobulinemia who acquired $\mathrm{HCV}$ infection from contaminated immunoglobulin show a high rate $(30 \%)$ of progression to cirrhosis $(90,91)$ related to an impaired B cell function (92). Progression rate seems to correlate to the immunosuppression degree. In relation to HBV infection, studies among renal transplant recipients have described mutations in the HBV core gene, mostly in patients with severe disease. The phenotype of these HBV variants in this population may indicate that they play a role in the pathogenesis of liver damage $(93,94)$.

Other populations at high risk for LC: Some occupational exposures have been related to liver carcinogenesis. Two studies conducted in Europe among workers from Armenia (95) and Moscow (96) exposed to chloroprene (derived from vinyl chloride) found an increase in the LC mortality (standardized mortality ratios: $3.39,95 \%$ CI 1.09 to 10.5 ; and 2.4, 95\% CI 1.1 to 4.3 , respectively). The problem in these studies is that the term 'LC' may largely correspond to other primary liver tumours than hepatocelluar carcinoma, such as angiosarcoma, which is associated with chemical carcinogens such as arsenic and vinyl chloride (97). Another study conducted in Sweden among grain millers found an increased LC incidence (standard incidence ratio 2.4) compared with that of the general population. This increase can be explained by the exposure to aflatoxins and pesticides (98).

In a case-control study conducted in Northern Italy, an elevated risk has been found among the first-degree relatives of LC cases (relative risk 2.4, 95\% CI 1.3 to 4.4) (99). This association is consistent with risk estimates from other studies (100), and it is not modified after adjustment for alcohol, tobacco consumption, and history of cirrhosis and hepatitis infection. The authors suggested that approximately $3 \%$ of the newly diagnosed LC cases are related to the familial component.

Opportunities for LC prevention: Chronic HBV infection is responsible for over $80 \%$ of the LC cases in South East Asia, China and sub-Saharan Africa, but only close to $20 \%$ of the LC cases in Europe. Chronic HCV infection is emerging as a major risk factor for $\mathrm{LC}$ in most western countries and Japan. Prevention of HBV infection is possible by immunization, and LC might be the first major human cancer preventable through vaccination. HBV vaccination trials have shown their efficacy in reducing HBV transmission and the prevalence of $\mathrm{HBsAg}$ carriers in high incidence areas in Africa (101), Asia (102) and Alaska (103). In countries at high risk for LC, HBV vaccination programs have demonstrated their efficacy, and a significative decline in the incidence of hepatocellular carcinoma has been shown among cohorts of vaccinated newborns and children in Taiwan, and in vaccinated adults in Korea $(104,105)$. These results follow and support the recommendation of the WHO of introducing HBV vaccination worldwide. Figure 7 shows the distribution of vaccination programs in Europe in 2000 (20).

$\mathrm{HCV}$ vaccines are not yet available, although several products are under trial. Prevention of HCV infection should be based on screening of blood products and on the implementation of educational programs among potential and high risk populations. HBV and HCV screening of blood products can effectively reduce the incidence of posttransfusional hepatitis (106). However, there is no direct evidence of the effect of this screening in the reduction of LC incidence. It has been postulated that syringe exchange programs in IDU populations could reduce transmission of HBV, HCV and HIV. However, studies to assess the efficacy of syringe exchange programs in preventing viral transmission show inconsistent results $(107,108)$.

\section{CONCLUSIONS}

The environmental factors involved in the etiology of LC are largely established and, in combination, they account for the majority of cases (more than 90\%) worldwide. Prevention of this common neoplasm is achievable through HBV immunization and aflatoxin exposure reduction in developing countries. In developed countries such as Europe, prevention might focus on the reduction of HBV and HCV infections as well as alcohol and tobacco consumption.

ACKNOWLEDGEMENTS: We thank Daniel Lavanchy for his helpful indications to obtain HBV and HCV prevalence data and to Mark Kane who provided data on the HBV vaccination programs in Europe. Mireia Díaz prepared the tables and graphs, and Pilar Martinez helped with the editing of the manuscript. This review was partially supported by a Spanish grant from the Fondo de Investigaciones Sanitarias (FIS98/1399). 


\section{REFERENCES}

1. Parkin DM, Whelan SL, Ferlay J, et al. Cancer Incidence in Five Continents, vol VII. Lyon: IARC Scientific Publications, 1997:143.

2. Parkin DM, Muir CS, Whelan SL, et al. Cancer Incidence in Five Continents, vol VI. Lyon: IARC Scientific Publications, 1992:120.

3. WHO Mortality Database. World Health Statistics Annuals. <http://www.who.int/whois/statistics> [version current at July 15, 2000]

4. Ferlay J, Parkin DM, Pisani P, eds. GLOBOCAN 1. Cancer Incidence and Mortality Worldwide. Lyon: ARC Press, 1998.

5. Parkin DM, Pisani P, Ferlay J. Estimates of the worldwide incidence of 25 major cancers in 1990. Int J Cancer 1999;80:827-41.

6. Pisani P, Parkin DM, Bray F, Feraly J. Estimates of the worldwide mortality from 25 cancers in 1990. Int J Cancer 1999;83:18-29.

7. International Classification of Diseases, eighth revision, adapted for use in the United States. Public Health Service Publication No 1693. Washington: Department of health, Education and Welfare, 1967.

8. International Classification of Diseases, 9th Revision, Clinical Modification. (DHHS No [PHS] 80-1260). Washington: Department of Health and Human Services, 1979.

9. Bouchardy C, Wanner P, Parkin DM. Cancer mortality among sub-Saharan African migrants in France. Cancer Causes Control 1995;6:539-44.

10. Khlat, M. Cancer in mediterranean migrants - based on studies in France and Australia. Cancer Causes Control 1995;6:525-31.

11. Swerdlow AJ, Marmot MG, Grulich AE. Cancer mortality in Indian and British ethnic immigrants from the Indian subcontinent to England and Wales. Br J Cancer 1995;72:1312-9.

12. Grulich AE, Swerdlow AJ, Head J, Marmot MG. Cancer mortality in African and Caribbean migrants to England and Wales. Br J Cancer 1992;66:905-11.

13. Geddes M, Balzi D, Buiatti E, Brancker A, Parkin DM. Cancer mortality in Italian migrants to Canada. Tumori 1994:80:19-23.

14. Stroffolini T, Andreone P, Andriulli A, et al. Characteristics of hepatocellular carcinoma in Italy. J Hepatol 1998;29:944-52.

15. De Vos Irvine H, Goldberg D, Hole DJ, McMenamin J. Trends in primary liver cancer. Lancet 1998;351:215-6. (Lett)

16. Benhamiche AM, Faivre C, Minello A, et al. Time trends and age-periodcohort effects on the incidence of primary liver cancer in a well-defined French population: 1976-1995. J Hepatol 1998;29:802-6.

17. Waetjen LE, Grimes DA. Oral contraceptives and primary liver cancer: temporal trends in three countries. Obstet Gynecol 1996;88:945-9.

18. Okuda K, Fujimoto I, Hanai A, Urano Y. Changing incidence of hepatocellular carcinoma in Japan. Cancer Res 1987;47:4967-72.

19. Okuda K. Hepatitis $C$ virus and hepatocellular carcinoma. In: Tabor E, Di Bisceglie AM, Purcell RH, eds. Etiology, Pathology, and Treatment of Hepatocellular Carcinoma in North America. Houston: PPC-Gulf Publishing Company, 1991.

20. Deuffic S, Buffat L, Poynard T, Valleron AJ. Modeling the hepatitis C virus epidemic in France. Hepatology 1999;29:1596-601.

21. Magnitude of HCV problem still not fully known. Viral Hepatitis. $<$ http://hgins.uia.ac.be/esoc/VHPB >. (Version current at July 15, 2000)

22. Bosch XB, Ribes J, Borràs J. Epidemiology of primary liver cancer. Semin Liver Dis 1999;19:271-85.

23. Tanaka K, Hirohata T, Fukuda K, Shibata A, Tsukuma H, Hiyama T. Risk factors for hepatocellular carcinoma among Japanese women. Cancer Causes Control 1995;6:91-8.

24. Evans AA, O'Connell AP, Pugh JC, et al. Geographic variation in viral load among hepatitis B carriers with differing risks of hepatocellular carcinoma. Cancer Epidemiol Biomarkers Prev 1998;7:559-65.

25. Wild CP, Hall AJ. Hepatitis B virus and liver cancer - Unanswered questions. Cancer Surv 1998;33:35-44.

26. Tabor E. Viral hepatitis and liver cancer. In: Goldin RD, Thomas HC, Gerber MA, eds. Viral Pathology of Viral Hepatitis. London: Arnold, 1998:161-77.

27. Di Bisceglie AM, Carithers RL, Gores GJ. Hepatocellular carcinoma. Hepatalogy 1998;28:1161-5.

28. Hepatitis Viruses, vol 59. IARC Monographs on the Evaluation of Carcinogenic Risks to Humans. IARC Scientific Publications. Lyon: International Agency for Research on Cancer, 1994.

29. Donato F, Boffeta P, Puoti M. A meta-analysis of epidemiological studies on the combined effect of hepatitis B and C virus infections in causing hepatocellular carcinoma. Int J Cancer 1998;75:347-54.

30. Pisani P, Parkin DM, Muñoz N, Ferlay J. Cancer and infection: estimates of the attributable fraction in 1990. Cancer Epidemiol Biomarkers Prev 1997;6:387-400

31. WHO. Expanded programme on immunization. Hepatitis B vaccine. <www.who.int/vaccines.surveillance/graphics/ htmls/hepbprev.htm>. [version current at July 15, 2000]

32. Hepatitis C: global prevalence. Wkly Epidemiol Rec 1997;72:341-8.

33. Current epidemiological trends of viral hepatitis world-wide (by region). Viral Hepatitis. <http://hgins.uia.ac.be/esoc/VHPB/> (Version current at July 15,2000$)$
34. Simonetti RG, Cammà C, Fiorello $\mathrm{F}$, et al. Hepatitis $\mathrm{C}$ virus infection as a risk factor for hepatocellular carcinoma in patients with cirrhosis. Ann Intern Med 1992;116:97-102.

35. Levrero M, Tagger A, Balsano C, et al. Antibodies to hepatitis C virus in patients with hepatocellular carcinoma. J Hepatol 1991;12:60-3.

36. Colombo M, Kuo G, Choo Q-L. Prevalence of antibodies to hepatitis C virus in Italian patients with hepatocellular carcinoma. Lancet 1989;ii:1006-8.

37. Tagger A, Donato F, Ribero ML, et al. A case-control study in GB virus $\mathrm{C} /$ hepatitis $\mathrm{G}$ virus infection and hepatocellular carcinoma. Hepatology 1997;26:1653-7.

38. Donato F, Tagger A, Chiesa R, et al. Hepatitis B and C virus infection, alcohol drinking, and hepatocellular carcinoma: a case-control study in Italy. Hepatology 1997:26:579-84

39. Bréchot C, Jaffredo F, Lagorce D, et al. Impact of HBV, HCV and GBV$\mathrm{C} / \mathrm{HGV}$ on hepatocellular carcinomas in Europe: results of a European concerted action. J Hepatol 1998;29:173-83.

40. Bruix J, Barrera JM, Calvet X, et al. Prevalence of antibodies to hepatitis $\mathrm{C}$ virus in Spanish patients with hepatocellular carcinoma and hepatic cirrhosis. Lancet 1989;ii:1004-6.

41. Vargas V, Castells L, Esteban Jl. High frequency of antibodies to the hepatitis $\mathrm{C}$ virus among patients with hepatocellular carcinoma. Ann Intern Med 1990;112:232-3.

42. Nalpas B, Driss F, Pol S, et al. Association between HCV and HBV infection in hepatocellular carcinoma and alcoholic liver disease. J Hepatol 1991;12:70-4.

43. Zavitsanos X, Hatzakis A, Kaklamani E, et al. Association between hepatitis $\mathrm{C}$ virus and hepatocellular carcinoma using assays based on structural and nonstructural hepatitis $C$ virus peptides. Cancer Res 1992:52:5364-7.

44. Hadziyannis S, Tabor E, Kaklamani E, et al. A case-control study of hepatitis $B$ and $C$ virus infections in the aetiology of hepatocellular carcinoma. Int J Cancer 1995;60:627-31.

45. Goritsas CP, Athanasiadou A, Arvaniti A, et al. The leading role of hepatitis $B$ and $C$ viruses as risk factors for the development of hepatocellular carcinoma. A case control study. J Clin Gastroenterol 1995;20:220-4.

46. Zaia G, Havelka J, Altorfer J, et al. Hepatitis-C-virus und hepatom. Schweiz M Med Wochenschr 1992;122:194-7.

47. Goeser T, Müller HM, Solbach C, Toex U, Kommerell B, Theilmann L. Hepatitis $\mathrm{C}$ virus, alcoholic cirrhosis, and hepatocellular carcinoma. Cancer Epidemiol Biomarkers Prev 1994;3:311-5.

48. Haydon GH, Jarvis LM, Simmonds P, Harrison DJ, Garden OJ, Hayes PC, Association between chronic hepatitis $\mathrm{C}$ infection and hepatocellular carcinoma in a scottish population. Gut 1997;40:128-32.

49. Fattovich G. Progression of hepatitis B and C to hepatocellular carcinoma in western countries. Hepatogastroenterology 1998;45:1206-13.

50. Caselmann WH, Alt M. Hepatitis C virus infection as a major risk factor for hepatocellular carcinoma. J Hepatol 1996;24(Suppl 2):61-6.

51. Pessoa MG, Terrault NA, Detmer J, et al. Quantitation of hepatitis G and $\mathrm{C}$ viruses in the liver: evidence that hepatitis $\mathrm{G}$ virus is not hepatotropic. Hepatology 1998;27:877-80.

52. Alter HJ, Nakatsuji Y, Melpolder J, et al. The incidence of transfusionassociated hepatitis $\mathrm{G}$ virus infection and its relation to liver disease. N Engl J Med 1997;336:747-54.

53. Alter MJ, Gallagher M, Morris TT, et al. Acute non-A-E hepatitis in the United States and the role of hepatitis $G$ virus infection. N Engl J Med 1997;336:741-6.

54. Nalpas B. Alcohol and hepatocellular carcinoma. In: Bréchot $\mathrm{CH}$, ed. Primary Liver Cancer: Etiological and Progression Factors. Boca Raton: CRC Press, 1994:231-45.

55. Vall Mayans M, Calvet X, Bruix L, et al. Risk factors for hepatocellular carcinoma in Catalonia, Spain. lnt J Cancer 1990;46:378-81.

56. Becker U, Deis A, Sorensen A, et al. Prediction of risk of liver disease by alcohol intake, sex, and age: a prospective population study. Hepatology 1996;23:1025-9.

57. Serfaty L, Chazouillères $\mathrm{O}$, Poujol-Robert $\mathrm{A}$, et al. Risk factors for cirrhosis in patients with chronic hepatitis $\mathrm{C}$ virus infection: results of a casecontrol study. Hepatology 1997;26:776-9.

58. Roudot-Thoraval F, Bastie A, Pawlotsky JM, Dhumeaux D. Epidemiological factors affecting the severity of hepatitis $\mathrm{C}$ virus-related liver disease: a French survey of 6,664 patients. The Study Group for the Prevalence and the Epidemiology of Hepatitis C Virus. Hepatology 1997;26:485-90.

59. WHO. Highlights on Health in Spain. European Communities and WHO. $<$ http://www.who.dk/country/country.htm>. [version current at March 1, 1997]

60. Trichopoulos D, Day NE, Kaklamani E, et al. Hepatitis B virus, tobacco smoking and ethanol consumption in the etiology of hepatocellular carcinoma. lnt J Cancer 1987;39:45-9. 
61. IARC Monographs on the Evaluation of the Carcinogenic Risk of Chemicals to Humans. Tobacco Smoking, vol 38. IARC Scientific Publications. Lyon: International Agency for Research on Cancer, 1986.

62. La Vecchia C, Tavani A, Franceschi S, Parazzini F. Oral contraceptives and cancer. Drug Saf 1996;14:260-72.

63. Mant JWF, Vessey MP. Trends in mortality from primary liver cancer in England and Wales 1975-92: Influence of oral contraceptives. Br J Cancer 1995; $72: 800-3$

64. Bosch FX, Muñoz N. Prospects for epidemiological studies on hepatocellular cancer as model for assessing viral and chemical interactions. In: Bartsch H, Hemminki K, O’Neill IK, eds. Methods for Detecting DNA Damaging Agents in Humans: Applications in Cancer Epidemiology and Prevention. IARC Scientific Publications No 89. Lyon: International Agency for Research on Cancer, 1988.

65. Campbell TC, Chen JS, Liu CB, Li JY, Parpia B. Non association of aflaxotin with primary liver cancer in a cross-sectional ecological survey in the People's of Republic of China. Cancer Res 1990;50:6882-93.

66. Joint FAO/WHO Expert Committee on Food Additives (JECFA). Toxicological Evaluation of Certain Food Additives and Contaminants. WHO food additives series 37. Geneva: WHO/IPCS, 1996.

67. Montesano R, Hainaut P, Wild CP. Hepatocellular carcinoma: from gene to public health. J Natl Cancer Inst 1997;89:1844-51.

68. Hsing W, McLaughlin JK, Olsen JH, et al. Cancer risk following primary hemochromatosis: a population-based cohort study in Denmark. Int J Cancer 1995;60:160-2.

69. Yang Q, McDonnell SM, Khoury MJ, Cono J, Parrish RG. Hemochromatosis-associated mortality in the United States from 1979 to 1992: an analysis of Multiple-Cause Mortality Data. Ann Intern Med 1998;129:946-53.

70. Stevens RG, Jones DY, Micozzi MS, Taylor PR. Body iron stores and the risk of cancer. N Engl J Med 1988;319:1047-52.

71. Knekt P, Reunanen A, Takkunen H, Aromaa A, Heliovaara M, Hakulinen T. Body iron stores and risk of cancer. Int J Cancer 1994;56:379-82.

72. Edwards CQ, Griffen LM, Goldgar D, Drummond C, Skolnick MH, Kushner JP. Prevalence of hemochromatosis among 11,065 presumably healthy blood donors. N Engl J Med 1988;318:1355-62.

73. McDonnell SM, Phatak PD, Felitti V, Hover A, McLaren GD. Screening for hemochromatosis in primary care settings. Ann Intern Med 1998;129:962-70.

74. Feder JN, Gnirke A, Thomas W, et al. A novel MHC class I-like gene is mutated in patients with hereditary hemochromatosis. Nat Genet 1996;13:399-408.

75. Bodmer JG, Parham P, Albert ED, Marsh SG. Putting a hold on "HLA-H". The WHO Nomenclature Committee for Factors of the HLA System. Nat Genet 1997;15:234-5.

76. Adami H-O, Chow W-H, Nyrén O, et al Excess risk of primary liver cancer in patients with diabetes mellitus. J Natl Cancer Inst 1996;88:1472-7.

77. Wideroff L, Gridley G, Mellemkjaer L, et al. Cancer incidence in a population-based cohort of patients hospitalized with diabetes mellitus in Denmark. J Natl Cancer Inst 1997;89:1360-5.

78. La Vecchia C, Negri E, Decarli A, et al. Diabetes mellitus and the risk of primary liver cancer. lnt J Cancer 1997;73:204-7.

79. Watson HG, Ludlam CA, Rebus S, Zhang LQ, Peutherer JF, Simmonds P. Use of several second generation serological assays to determine the true prevalence of hepatitis $\mathrm{C}$ virus infection in haemophiliacs treated with non-virus inactivated factor VIII and IX concentrates. Br J Haematol 1992;80:514-8

80. Mauser-Bunschoten EP, Bresters D, van Drimmelen AA, et al. Hepatitis C infection and viremia in Dutch hemophilia patients. J Med Virol 1995;45:241-6.

81. Darby SC, Ewart DW, Giangrande PLF, et al. Mortality from liver cancer and liver disease in haemophilic men and boys in UK given blood products contaminated with hepatitis C. UK Haemophilia Centre Directors' Organisation. Lancet 1997;350:1425-30.

82. Levine OS, Vlahov D, Nelson KE. Epidemiology of hepatitis B virus infections among injecting drug users: seroprevalence, risk factors, and viral interactions. Epidemiol Rev 1994;16:418-36.

83. Ghodse H, Oyefeso A, Kilpatrick B. Mortality of drug addicts in the United Kingdom 1967-1993. Int J Epidemiol 1998;27:473-8.

84. Goedert JJ, Pizza G, Gritti FM, et al. Mortality among drug users in the AIDS era. Int J Epidemiol 1995;24:1204-10.

85. Pol S, Lamorthe B, Thi NT, et al. Retrospective analysis of the impact of HIV infection and alcohol use on chronic hepatitis $\mathrm{C}$ in a large cohort of drug users. J Hepatol 1998;28:945-50.

86 García-Samaniego J, Soriano V, Castilla J, et al. Influence of hepatitis C virus genotypes and HIV infection on histological severity of chronic hepatitis C. Am J Gastroenterol 1997;92:1130-4

87. Beld M, Penning M, Lukashov V, et al. Evidence that both HIV and HIV- induced immunodeficiency enhance HCV replication among HCV seroconverters. Virology 1998;244:504-12.

88. Piroth L, Duong M, Quantin C, et al. Does hepatitis C virus co-infection accelerate clinical and immunological evolution of HIV-infected patients? AIDS 1998;12:381-8.

89. Fraumeni JF, Hoover R. Immunosurveillance and cancer: epidemiologic observations. Natl Cancer Inst Monogr 1977;47:121-6.

90. Bjorkander J, Cunningham-Rundles C, Lundin P, Olsson R, Soderstrom R, Hanson LA. Intravenous immunoglobulin prophylaxis causing liver damage in 16 of 77 patients with hypogammaglobulinaemia or IgG subclass deficiency. Am J Med 1988;84:107-11.

91. Bjoro K, Froland SS, Yun Z, Samdal HH, Haaland T. Hepatitis C infection in patients with primary hypogammaglobulinaemia after treatment with contamined immune globulin. N Engl J Med 1994;331:1607-11.

92. Collier J, Heathcote J. Hepatitis $\mathrm{C}$ viral infection in the immunosuppressed patient. Hepatology 1998;27:2-6.

93. Gunther S, Baginski S, Kissel H, et al. Accumulation and persistence of hepatitis B virus core gene deletion mutants in renal transplant patients are associated with end-stage liver disease. Hepatology 1996;24:751-8.

94. Gunther S, Piwon N, Iwanska A, Schilling R, Meisel H, Will H. Type, prevalence and significance of core promoter/enhancer II mutations in hepatitis B viruses from immunosuppressed patients with severe liver disease. J Virol 1996;70:8318-31.

95. Bulbulyan MA, Margaryan AG, Ilichova SA, et al. Cancer incidence and mortality in a cohort of chloroprene workers from Armenia. Int J Cancer 1999;81:31-3.

96. Bulbulyan MA, Changuina OV, Zaridze DG, Astashevsky SV, Colin D, Boffetta P. Cancer mortality among Moscow shoes workers exposed to chloroprene (Russia). Cancer Causes Control 1998;9:381-7.

97. Vainio H, Matos E, Kogevinas M. Identification of occupational carcinogens. In: Pearce N, Matos E, Vainio H, Boffetta P, Kogevinas M, eds. Occupational Cancer in Developing Countries. IARC Scientific Publications, No 129. Lyon: IARC Scientific Publications, 1994:41-59.

98. Alavanja MC, Malker H, Hayes RB. Occupational cancer risk associated with the storage and bulk handling of agricultural foodstuff. J Toxicol Environ Health 1987;22:247-54.

99. Fernández E, La Vecchia C, D’Avanzo B, Negri E, Franceschi S. Family history and the risk of liver, gallbladder, and pancreatic cancer. Cancer Epidemiol Biomarkers Prev 1994;3:209-12.

100. Chen CJ, Liang KY, Chang AS, et al. Effects of hepatitis B virus, alcohol drinking, cigarette smoking and familial tendency of hepatocellular carcinoma. Hepatology 1991;13:398-406.

101. Whittle HC, Maine N, Pilkington J, et al. Long-term efficacy of continuing hepatitis B vaccination in infancy in two Gambian villages. Lancet 1995;345:1089-92.

102. Hsu HM, Chen DS, Chuang CH, et al. Efficacy of a mass hepatitis B vaccination program in Taiwan. JAMA 1988;260:2231-5.

103. Purcell RH. Prospects for prevention of Hepatitis types B and C in North America. In: Tabor E, Di Bisceglie AM, Purcell RH, eds. Etiology, Pathology and Treatment of Hepatocellular Carcinoma in North America. Advances in Applied Biotechnology Series, vol 13. Texas: The Portfolio Publishing Company, 1991:343-54.

104. Chang MH, Chen CJ, Lai MS, et al. Universal hepatitis B vaccination in Taiwan and the incidence of hepatocellular carcinoma in children, Taiwan Childhood Hepatoma Study Group. N Engl J Med 1997;336:1855-9.

105. Lee MS, Kim DH, Kim H, et al. Hepatitis B vaccination and reduced risk of primary liver cancer among male adults: a cohort study in Korea. Int J Epidemiol 1998;27:316-9.

106. González A, Esteban JI, Madoz P, et al. Efficacy of screening donors for antibodies to the hepatitis $\mathrm{C}$ virus to prevent transfusion-associated hepatitis: final report of a prospective trial. Hepatology 1995;22:439-45.

107. Hagan H, McGough JP, Thiede H, Weiss NS, Hopkins S, Alexander ER. Syringe exchange and risk of infection with hepatitis $B$ and $C$ viruses. Am J Epidemiol 1999;149:203-313.

108. Hagan H, Jarlais DC, Friedman SR, Purchase D, Alter MJ. Reduced risk of hepatitis $\mathrm{B}$ and $\mathrm{C}$ among participants in a syringe exchange program. Am J Public Health 1995;85:1531-7.

109. Austin $\mathrm{H}$. The role of tobacco use and alcohol consumption in the aetiology of hepatocellular carcinoma. In: Tabor E, Di Bisceglie AM, Purcell RH, eds. Etiology, Pathology and Treatment of Hepatocellular Carcinoma in North America. Advances in Applied Biotechnology Series, vol 13. Texas: The Portfolio Publishing Company, 1991:57-75.

110. Kew MC, Di Bisceglie AM, Paterson AC. Smoking as a risk factor in hepatocellular carcinoma. A case-control study in Southern African blacks. Cancer 1985;56:2315-7.

111. Kew MC, Song E, Mohammed A, Hodkinson J. Contraceptive steroids as a risk factor for hepatocellular carcinoma: a case-control study in South African black women. Hepatology 1990;11:298-302. 


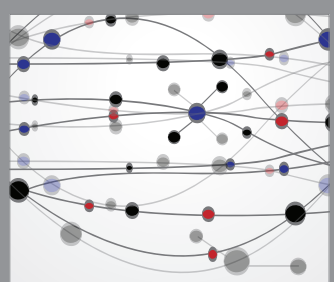

The Scientific World Journal
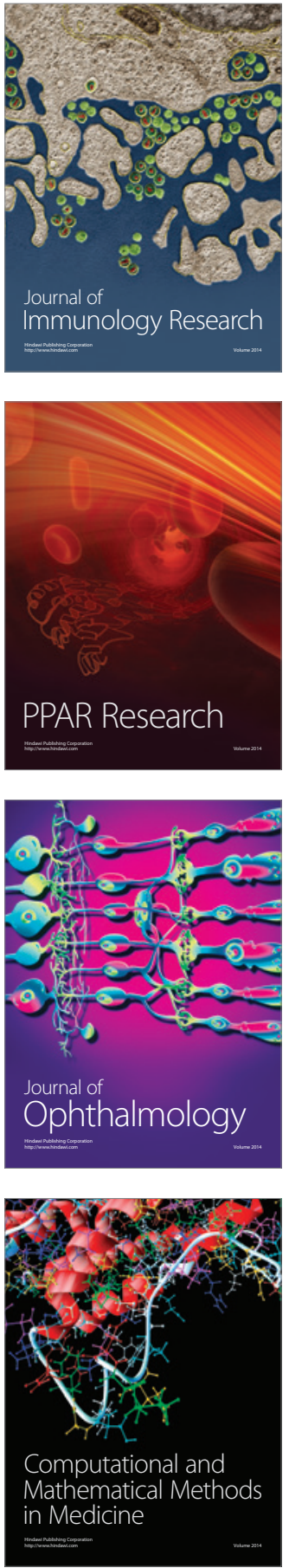

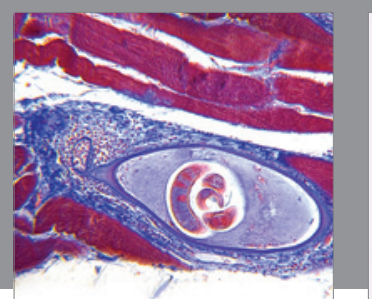

Gastroenterology Research and Practice

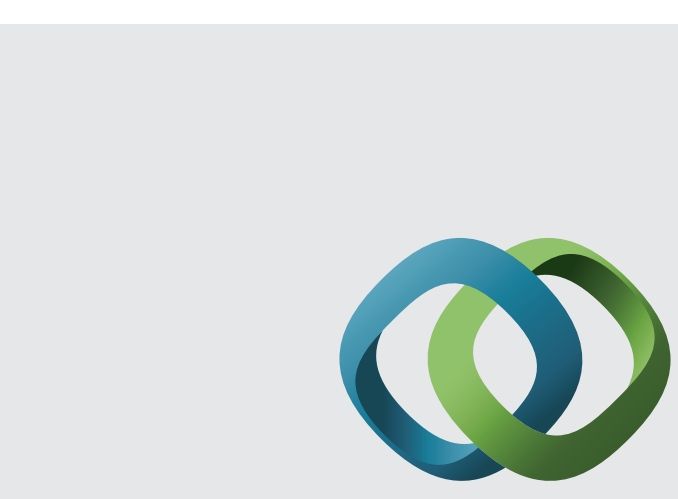

\section{Hindawi}

Submit your manuscripts at

http://www.hindawi.com
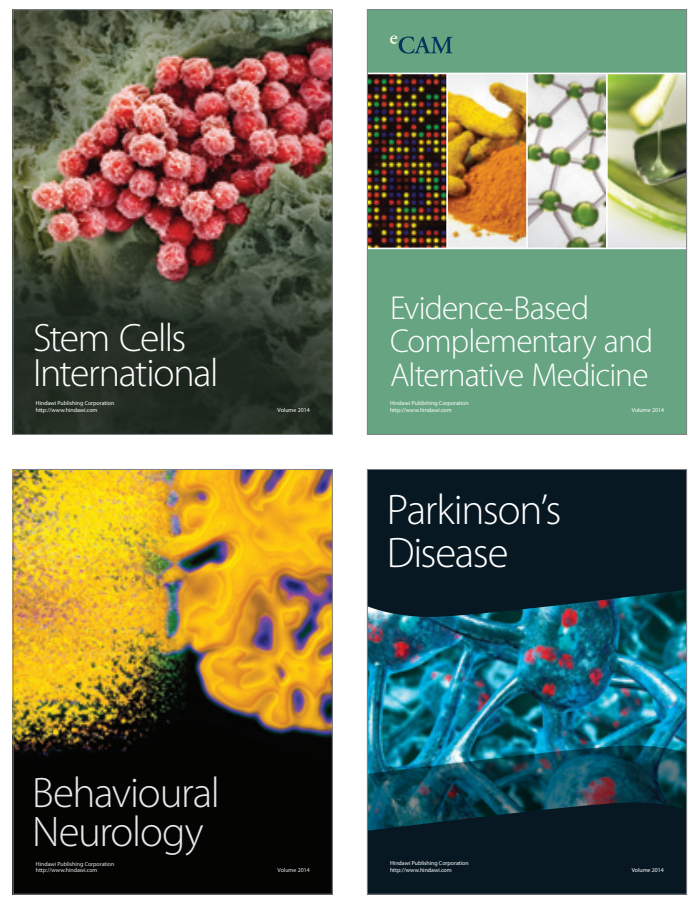
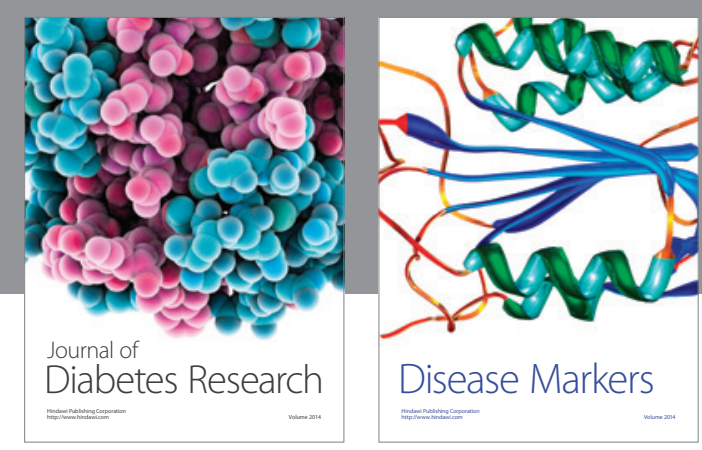

Disease Markers
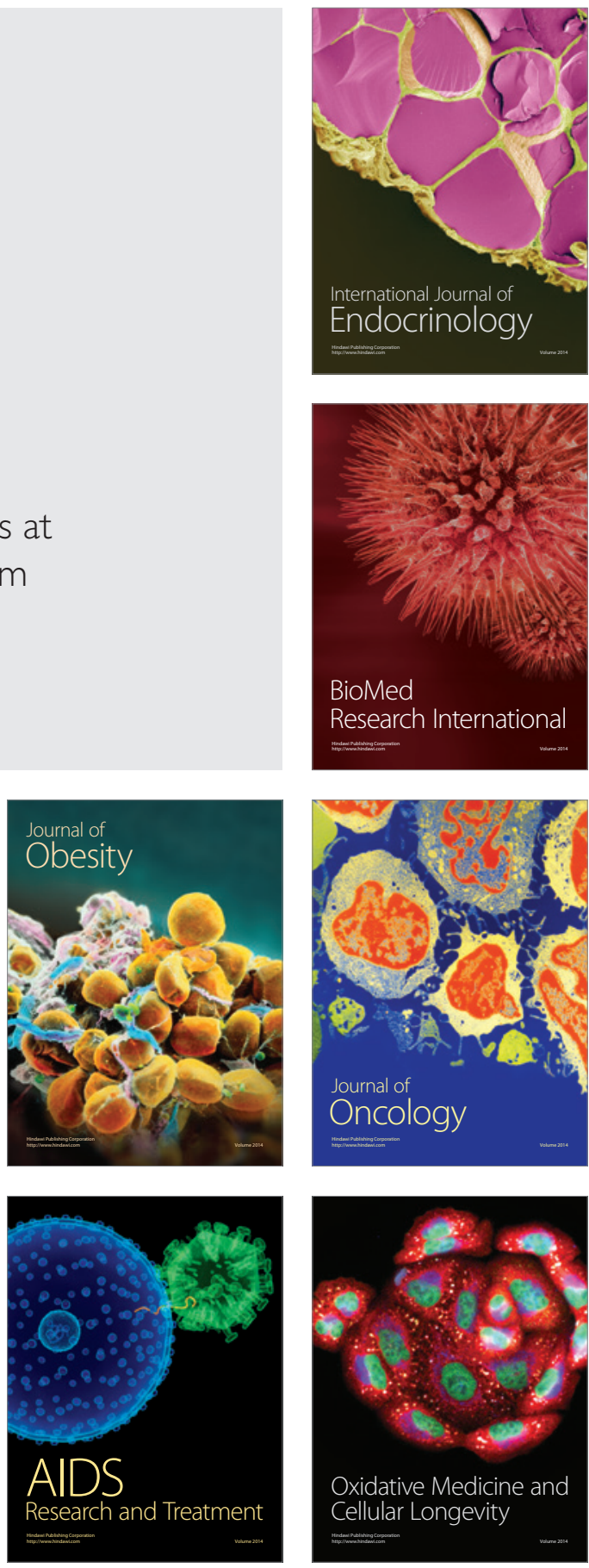